\title{
Socialization of Knowledge through Collaborative Projects. The Renovarte Café Case
}

\author{
M.A. Ricardo Ortiz Ayala*, Ana Rosa Hernández Jiménez, Irma Rivera Gordillo y Marisol, Amparo Ríos Hoyo \\ Facultad de Contaduría y Administración, Universidad Autónoma de Querétaro, México \\ *Corresponding author: ricardoortizayala@gmail.com
}

Received November 03, 2014; Revised January 13, 2015; Accepted February 25, 2015

\begin{abstract}
This research was based on Nonaka and Takeuchi's (1995) theory about the creation and management of knowledge. The aspect of it that is considered mainly is knowledge. Socialization. This is the case of RenovArte Café, a project for which the main guidelines were collaborative work and teamwork. Students of the subject of marketing from the Instituto Tecnológico de Querétaro and the Univeridad Autónoma de Querétaro worked jointly and together with the business proprietor as well. The Educational Plan for the Period 2007-2012 (SEP, 2007) states that its objective number four: the importance of developing an integral education in order to fortify personal values, competitiveness and the generation of knowledge in the classroom and to develop the teaching process with the help of the institutional environment. Part of the strategy emphasizes the idea of developing professional projects together with businesses to permit the students to put into practice their knowledge. The constructivist approach emphasizes in a more active role from students, generating their learning experiences (UAQ 2013). The role of making socially practical [creating nexus between education and business] and collaborating in the formation of the student of higher education is such that the Universidad Autónoma de Querétaro is developing specific activities to promote and reinforce this task as a part of the functions of the Direction of External Relations of the University (UAQ 2013), and through that accomplish objectives such the Promotion of coordinated efforts between the institutions and organizations of the social, public and private sectors: that is, facilitate the ability of exchanging experiences, information, knowledge and work" and "Expand the socially practical university links and launch different projects".
\end{abstract}

Keywords: knowledge socialization, collaborative work, marketing

Cite This Article: M.A. Ricardo Ortiz Ayala, Ana Rosa Hernández Jiménez, Irma Rivera Gordillo y Marisol, and Amparo Ríos Hoyo, "Socialization of Knowledge through Collaborative Projects. The Renovarte Café Case.” American Journal of Educational Research, vol. 3, no. 3 (2015): 259-262. doi: 10.12691/education-3-3-1.

\section{Introduction}

How do public universities make practical what students learn when they are doing a collaborative project about marketing communication? This question leads to the present research, developed from the perspective of the knowledge management theory-specifically the knowledge spiral proposed by Nonaka and Takeuchi (1995), who claim that knowledge is created and transformed continuously through four stages: socialization, exteriorization, combination and internalization-meaning that students first understand, then see how what they know can be put into practice, then have theory enrich their practical knowledge, and finally, make that knowledge their own, in other words, master what they know. During the July-December 2012 semester, ten collaborative projects were developed jointly between the Facultad de Contaduría y Administración of the Universidad Autonomade Queretaro (Mexico) and the Department of Economic-Administrative Sciences of the Instituto Tecnológico de Queretaro (Mexico). At the end of the course, the results of the projects were presented before a jury of professors from both institutions, and they were granted a Mention signed by authorities from both Universities.The guest teachers gave a special mention to three of the projects which they considered to be the best. Among these three was the "RenovArte Cafe" project, developed by the students Irma Rivera Gordillo, Arlette Lucas Suárez, Erika Velázquez Aguilar, Manuel Basurto Soria and Ivan Gomez Rodriguez.

The entrepreneur Phillip Jones arrived to the City of Queretaro, and in 2009 decided to take a bartending course to improve his technique in the preparation of coffee. He opened his coffee shop RenovArte Café, which opened in November 2010, and its proprietor, Mr. Jones defines the mission of his business as follows: "RenovArte is a place that goes beyond a the mere concept of a coffee shop. It is a place where you can interact with people, chat and look for answers to the most important matters in life: in other words, it is a space of your own".

The first step was to meet with the members of the teams. Each team was formed by students of both institutions. Each team was assigned to search for a company or business for which they would develop suggestions for improvement. Here the objective was to apply the knowledge they acquired at school to the daily activities of those companies or businesses, trying, 
meanwhile, to involve the business owners or directors of the companies. The activities that followed through in the collaboration agreement with a company or business are supported by constructivist theoretical-methodological proposals. These proposals promote a reciprocal influence among the members of the teams who shared ideas and knowledge they had about business, in general. The involvement of the business owner or director/s was very important, as it constitutes the third element needed in order to achieve completion and cross references of the collaborative project. This study specifically aims to describe how marketing knowledge is shared through a collaborative project.

\section{Literature Review}

The Universidad Autónoma de Queretaro (2013) states, very specifically, as a part of the vision of the Facultad de Contaduría y Administration, the importance of forming student values, aptitudes, attitudes, abilities, capacities and knowledge which will lead them to a real connection with society in order to fulfill its needs. In the Faculty's Mission Statement it is mentioned that knowledge must be generated, applied and made public not only through programs of study but through innovation and interdisciplinary cooperation.

The vision of InstitutoTecnológico de Queretaro emphasizes on the importance of the "quality of their students in the fields of research, innovation and technological development by which they contribute to the regional, national and international strengthening” (ITQ, 2013). No doubt a way to achieve this vision is through the interaction with the economic and organizational environment before the students even finish studying their major. This is a way of making socially practical and linking the educational environment with the business environment.

The university constitutes an interesting world where students can obtain knowledge, but there remains the concern of how this knowledge will be put into practice in the labor world. It is important for students to share the knowledge they have obtained in order to understand its implications (Servin, 2005) and appreciate it as the most valuable of resources.

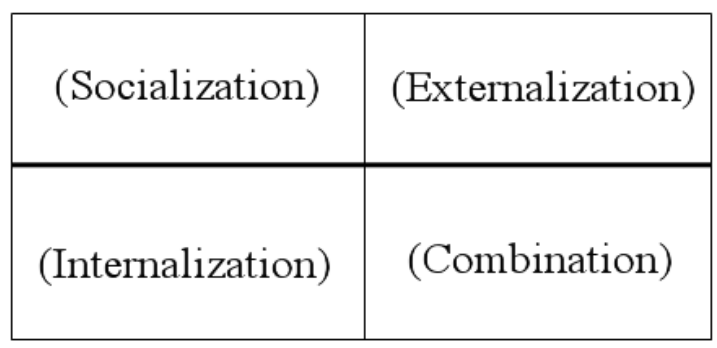

Figure 1. Four ways of knowledge conversion

According to Nonaka and Takeuchi (1995), the tacit and explicit knowledge are not separate entities, but complementary ones. There is an interaction and exchange of the creative activities of the human beings. The theory says that the human knowledge is created and expanded through social interaction of tacit and explicit knowledge. Nonaka and Takeuchi call this interaction, conversion of knowledge. This conversion is a social process among individuals and it is not confined to the interior of one individual. Through this process of social conversion, the tacit and explicit knowledge are expanded both in quantity as in quality.

If it is assumed that knowledge is created through the interaction between tacit and explicit knowledge, and four forms of knowledge result from this: 1 . Tacit to tacit knowledge, which is called socialization; 2. Tacit to explicit knowledge, which is called exteriorization; 3. Explicit to explicit knowledge, which is called combination, and 4. Explicit to tacit knowledge, which is called internalization (Nonaka and Takeuchi 2005).

\subsection{Socialization: Tacit to Tacit Knowledge}

It consists on sharing experiences and creating knowledge as well as shared mental models and technical abilities. "The apprentices work with their teachers and they learn their trade, not through words, but through observation, imitation and practice”. The key to get the tacit knowledge is practice. Without some form of shared experience, people have difficulty in projecting themselves to the process of thought of someone else.

\subsection{Externalization: Tacit to Explicit Knowledge}

Is the process in which tacit knowledge becomes explicit and adopts the form of metaphors, analogies, concepts, hypotheses or models. When the expressions are inappropriate, inconsistent and insufficient, such discrepancies and missing information between the images and expressions promote reflection and interaction among individuals. Exteriorization is observed in the process of creation of concepts and it is generated by the dialog or the collective reflection.

\subsection{Combination: Explicit to Explicit Knowledge}

It is a process of systematization of concepts with which a system of knowledge is generated. The individuals exchange and combine knowledge through various means, such as documents, meetings, telephone conversations or social networks. The reconfiguration of the information that is made through classification, addition, combination and categorization of the explicit knowledge can lead to obtaining new knowledge.

\subsection{Internalization: Explicit to Tacit Knowledge}

This process is related with "learning by doing”. In order for the organizational knowledge to be generated, it is necessary that the tacit knowledge accumulated on an individual level be shared with other members of the organization, beginning thus a new spiral of creation of knowledge.

All Healthy Organizations create and use knowledge. When organizations interact with their environments, they absorb information, make informed and take actions based on the combination of that knowledge and experiences, values and norms. (Davenport and Prusak, 1998)

(Wiig, 2007) In the search to be competitive, managers are looking for different ways to improve. They may use 
Knowledge for business benefit, seeking for better performance and results, managers must integrate knowledge process.

\section{Methodology}

The present research describe the way in which the marketing knowledge is shared, in this case a business providing services established in the city of Queretaro, México. This case study describe the real-life context in which activities occurred (Yin, 2003).

Type of Research: It's a case of study using an approximation to a qualitative interpretation analysis for the Owner, employees and students who designed the project and for the business, both directly related to the process of service providing, as well as related in the execution of the marketing activities involved in the project.

Information Sources: Semi-structured interviews will be done to both the students that developed the project, the owner and the employees, both directly related to the project, as well as involved in the execution of the marketing activities involved in the project.

Process: the information obtained will be analyzed and classified in order to see where common opinions about the way in which knowledge was socialized.

Material Resources: the resources used were of bibliographic type, face-to-face interviews, online and video resources.

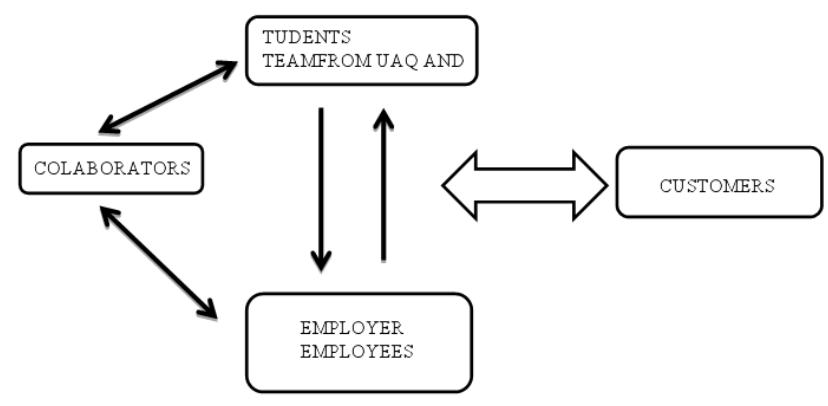

Figure 2. Interactions in RENOVARTE project

\section{Results of the Study}

The key elements in the Project were the students, the owner, the employees and of course the consumers. This chart indicates how the flow of information happened. At a certain point, the team of students of both InstitutoTecnologicode Querétaro and Universidad Autónoma de Querétaro undertook the leadership of this activity, and the lines of communication with the proprietor are also indicated in this chart. There was communication with the proprietor at all times.

The difficulties that arose were overcome through communication among the students team, and when necessary with the proprietor, who was always open to interventions and who wanted the project to generate ideas of improvement.

This communication resulted, for the students, an expertise in explicit marketing knowledge, and for the proprietor and his business, and his staff, the knowledge of their own processes, and further knowledge of their mission and vision. In this way collaboration was shown in the phases of socialization and externalization of the spiral of creation of organizational knowledge.

The dialog or collective reflection (externalization) allowed the generation of marketing strategies that allowed the company to get further self-knowledge and their customers to live an experience that makes them feel at home.

The interaction between the students and the business generated:

a) STOW Matrix. This is an activity that the proprietor had already undertaken in several occasions, so he shared his previous experiences and a new stow matrix was generated from an also new analysis.

b) Exploratory market research in order to determine the level of knowledge of the concept of the business and all what RenovArte café implies. This study also gave indicators about the perception that the public has of the business, expectations, demography and opportunity areas.

c) A one-day campaign directed to the non-captive consumers, with less knowledge of the business. This campaign included advertising through leaflets, banners, social networks and free product promotion handling, which meant that the members of the student team interacted and attended the consumers themselves, and even prepared products for them (tacit knowledge).

d) Making of a promotional video with the goal of advertising and publicizing the concept of the business. It was a professional-made video, which showed everyday scenes in the coffee shop and whose goal was to capture images which represented the essence of RenovArte café. This video is available in the social networks and webpages which allow the publication of this material.

e) Presentation of information to the captive consumers, whose knowledge of the business had been taken for granted.

f) Writing of a thank-you letter to suppliers as a way to strengthen the relationships within the chain supply, because they also contribute to the "experience" provided in the coffee shop through the quality of their products.

g) Research with municipality authorities about the process of registry of a trademark before the IMPI, something that the proprietor had wanted to do, and there were advances in the sense that the proprietor was informed of all the necessary requirements to apply for the trademark, and the cost was much lower to the information he had. The registration of his trademark is a short-term owner's objective.

The following two are some proposals that were made to the proprietor, which he consider to implement in the show term:

- Introduction of Dayketing as a strategy to increase familiarity with customers, which includes celebrating important dates for him (the customer).

- Modifications in the lay-out of the business in order to provide more comfort to the customer.

\section{Conclusions}


The research was useful to RenovArte Café in that it specifically addressed areas of need in market research and marketing strategy. Through the collaborative project, team discovered that there was a lack of promotion and awareness of the café amongst students from the other local university (UAQ-ITQ) and the clear need to embark on general and specific marketing initiatives. Through this project they were able to increase awareness of the business and capture new clients as well as boost revenue on a short-term basis.

The research could influence public policy in the way that it generates a new link between educational institutions and local business. In the past, links have been primarily between big business and universities, however, they discovered the value of working together with a small business where change can be rapidly implemented. This could translate into further government initiatives reinforcing this link and helping both students and SMEs.

This research is contributing to the body of knowledge in the way that it uses a new way of working between institutions and business and extends industry-based learning opportunities.

Our local community has been impacted by the application of the research in the local business studied and the educational institutions involved. RenovArte Café's business was improved through the use of the outputs of the research and the students were enriched by the hands on experience of working in a live business situation.

The key problem identified through the research was a lack of marketing strategy and business awareness in the local community. This was addressed by several recommendations and implemented through the use of a strategic marketing event in RenovArte Café leading to an immediate increase in sales and repeat customers. The business was able to progressively implement several of the recommendations put forward by the research and is now functioning with a better positioned marketing program including signage and customized promotions to key customers.

In general terms, the perception of the experience by both the team and the owner regarding the socialization and externalization of the knowledge shared in this collaborative project, constituted, for the students, an opportunity to experience teambuilding values, living practical situations in the business world and developing knowledge; for the proprietor it meant benefits in the sense that the initial expectations were achieved: increase self-knowledge of RenovArte café and reinforcement of the business' mission.

\section{References}

[1] Davenport, T., andPrusak, L. (1998). How Organizations Manage What They Know. Cambridge, MA: Harvard Business School Press.

[2] Leonard-Barton, D. (1995). Wellsprings of Knowledge: Building and Sustaining the Sources of Innovation. Harvard Business SchoolPress.

[3] Nonaka, I. y Takeuchi, H. (1995). The Knowledge-Creating Company. Nueva York, Nueva York. Oxford University Press.

[4] SEP (2007). Programa Sectorial de Educación 2007-2012, obtenido desde http://promep.sep.gob.mx/infgene/prog_sec.pdf [on line agosto 2012].

[5] Servin, G. (2005). ABC of Knowledge Management. Extract from NHS National Library for Health. From http://www.fao.org/fileadmin/user_upload/knowledge/docs/ABC_ of_KM.pdf [on line on July 2012]

[6] ITQ (2013). Misión y Visión. En línea el 14 de febrero de 2013. En http://www.itq.edu.mx/administracion/calidad/misionyvision.pdf

[7] UAQ (2013). Misión y Visión. En línea el 14 de febrero de 2013 en http://fca.uaq.mx/files/quienes_somos_mision.html

[8] UAQ (2013). Modelo y Lineamiento Educativo. En línea el 14 de febrero de 2013 en http://fca.uaq.mx/files/quienes_somos_modelo.htm

[9] Wiig, K. M. (1997) Knowledge Management: An Introduction and Perspective. The Journal of Knowledge Management.

[10] Yin, R. (1994). Case Study Research. Edit. Sage publications. London. United Kingdom. 